\title{
Care and Education of Children, Youth, and Adults in the Wilno Voivodship (1920-1939)
}

\author{
Stefania Walasek
}

University of Wroclaw, Department of Historical and Pedagogical Sciences, Institute of Pedagogy, ul. J. W. Dawida 1, 50-527 Wrocław, Poland, s.walasek@wnhip.uni.wroc.pl

\begin{abstract}
After the First World War educational and social activists joined in the work for the Vilnius voivodship community. Certain problems left over from the times of the Russian occupation were noticed in, among others, care and material support for various social groups as well as upbringing and education. The number of diverse issues of economic, social, and educational nature was increasing, and it was necessary for private individuals, organisations, and associations to participate in providing care, upbringing, and education to solve the problems. In the present paper the questions of organising institutions for children, youth, and adults: participants of the interactions in care and education are presented on the basis of the source materials stored in National Archive of Lithuania and the National Historical Archive in Wilno.
\end{abstract}

Keywords: care, upbringing, education, Wilno voivodship.

\section{Introduction}

The south-eastern borderlands of the Second Republic of Poland were among the economically poor regions of the country. These areas belonged to the Vilnius and Nowogródek voivodships, and partly to the Białystok and Polesie voivodships. Stanisław Srokowski postulated that the following actions had to be taken in the discussed region: "Nearly everything needs to be done here, which with the poor soil and the lack of any natural resources whatsoever, and with the uncared for farming population (on average over $85 \%$ ) appears to be a particularly burdensome task" (Srokowski, 1930). The work 
that had to be carried out in the region was delegated by the central government to the regions themselves, represented by the local government. "The needs of a given region are expressed through its local authorities. The local government is capable of making the best decisions about the importance of the whole set of local needs and the order in which resources are to be distributed in order to fulfil them. A well-organised local government, supported by responsible citizens, can undertake grassroots efforts to fulfil local needs. Simultaneously, the local government is a school of citizens. It is beneficial for the citizens as it educates in issues of the public as well as the entirety of the state system" (Hartleb-Wojciechowska, 1937).

Local governments' tasks encompassed various forms of economic and cultural activity of a particular region. These included, among others, problems connected with road infrastructure, farming, public healthcare and education. The last of the local governments' working areas - education - included combating illiteracy and building, organising, and maintaining state schools. Local governments played a major role in organising extracurricular education, e.g., courses for adults, day rooms, reading rooms, and libraries were organised in cooperation with state school authorities.

However, what was still left unorganised were the problems that were also a part of "education", such as, e.g., nurseries and orphanages, which, as it turned out, were typically established and ran by social and educational associations, the Catholic Church, and private individuals.

While organisation and maintenance of nurseries was a task of the local authorities, the question of, for example, orphanages, belonging to the Social Services government department, was the prerogative of the administration at the voivodship level. So was the case with health camps, which were to be organised by the health department and financed on the voivodship level by a team of Voivodship Office officials.

The high number of tasks related to education and upbringing, as well as the lack of clarity as to the competences of the particular agencies of government, local government, and voivodship administration led to difficulties in the implementation of their goals. That is why the effectiveness of the work connected with education, upbringing, and additional schooling of children and youth would often depend on the initiative of individuals and teams which included the aforementioned tasks in the charters of the institution that they independently established.

\section{Care and education of schoolchildren}

In the present paper the care and education institutions, vocational schools, professional skills training courses and adult education centres established and ran in Wilno and the Wilno voivodship by private individuals and associations are discussed. The aim of all those quite divergent forms of educational work and vocational training was 
to prepare the children and youth from poor families for work in their adulthood. The questions of upbringing were of no lesser importance. Children from culturally neglected environments would require teachers' support in shaping citizen attitudes, gaining social skills, learning to respect others, and shaping a proper attitude towards professional and family duties.

The "Świt" ("The Dawn") association, established in 1916, was one of the Wilno-based associations active in education, which organised day rooms in state schools, and clubs for children and youth. The idea behind the day rooms was to "protect children from the destructive influence of life in the streets, demoralisation caused by idleness and standing in lines to buy food" (Youth and children's clubs in Vilnius). The activists of the society claimed that mendicancy and vagrancy were common among children. In 1921 the association organised day rooms in state schools number: 6, 9, 13, 14, 18, 22, 39. The day rooms were intended for students of the particular state schools aged 10 to 14 . The group activities were organised in the afternoon, after classes, between 3 and 5 PM. The activities among which the interested participants could choose were bookbinding, shoemaking, woodworking, making toys and paper slides, knitting, and sewing. In 1921 over 300 state school students took part in the classes organised by the "Świt" association. In the summer the association would organise camps instead of day rooms. The food for the children on the camps was provided by the American kitchen.

In May, the favourable evaluation of the day room activities provided by the association lead to the decision to start a new day room/club at the Emergency Service for children and youth. The work with children started with games to move on to practical activities connected with vocational training. The education offered to young people aged 14 to 18 was diverse and adapted to the age of the students. It included making paper slides, singing, reading, storytelling, exercise, games and dances, shoemaking, and bookbinding. Field trips were often organised, as well. The organisation of the classes was supervised by Pelagia Kubicka and Jadwiga Mączyńska.

\section{Care for youngest children: nurseries}

The aforementioned Emergency Service was an outstanding centre providing various forms of care: emergency medical help for children, a small hospital, a nursery, a "Świt" school, two clubs for children: one at the school, and one at the nursery of the Emergency Service.

Emergency Service, organised by the Childcare Association of Wilno (Wileńskie Towarzystwo Opieki nad Dziećmi), was established in 1901 by J. Montwiłło in order to fulfil the urgent need to provide care and help for abandoned children. The aim of the Emergency Service was "to shelter abandoned children and those temporarily uncared for. The need was urgent, because starvation, poverty, and typhoid fever were 
decimating the population". In the police stations there were many lost children of the First World War refugees. "The children were so emaciated and ill that no nursery was sufficiently equipped to take care of them". Children stayed at the Emergency Service until their parents or guardians came to pick them up. During the 5 years between 1916 and 1921 over 2,000 children received help at the Emergency Service. A certain percentage of the ill and the weak remained in the Emergency Service nursery, in which up to 150 children could stay. Children that required specialist medical attention stayed in the hospital (40 beds).

In numerous documents the Emergency Service is referred to as a shelter because it was financed by the government as such. However, the received funds were insufficient: a 1922 letter to the Social Services Department (Wilno Childcare Association to the Social Services Department with the Government Delegate in Wilno, 1922) informing that there were 62 repatriates from Wilno in the shelter may serve as a proof. What is more, the problem of the increasing number of homeless children urgently requiring help and care was described. That association did not have the finances necessary to solve these issues, hence the application for a subsidy to provide for the sheltered children.

At the beginning of the 1920 in Wilno the question of abandoned children and orphans became a major problem for social service organisations and the city officials. On the one hand, it was necessary to provide basic housing and food, and on the other, organisation of the education and upbringing of the children became a challenge.

Yet another institution undertook the task of providing care for children was the "Temperance and Labour" Association (“Towarzystwo "Powściągliwość i Praca”), established by pr. N. Dyakowski, a social worker recognised in the Wilno community. The association run a boarding school for 120 students in Wilno and a shelter for 60 boys in Rejterów (Office of the Government Delegate in Wilno. Labour and Social Services Department).

However, through 1920-1921 the association would concentrate on internal conflicts between the members of the board and other members of the association instead of providing help. It was only after pr. Karol Lubianiec became the chairman of the "Temperance and Labour" Association in 1922 that the situation went back to normal and the work in education and upbringing developed. Pr. K. Lubianiec was recognised in the Wilno community for his work in various forms of help and education for children, youth, and adults. At the same time, he was a long-standing chairman of the "Home of the Heart of Jesus" Association (Towarzystwo "Dom Serca Jezusowego") that he had himself established. Supervising the boarding schools of both the associations allowed pr. Lubianiec to manage the institutions more effectively. The high evaluation of these centres by the Government Delegate in Wilno allowed the priest to receive financial support.

In 1922 pr. K. Lubianiec discussed the situation of his centres in a letter to the Social Services Department in Wilno. The boarding schools housed students returning from Pomerania and Russia. He had to prepare rooms for them, "find beds, bed sheets, and clothes for them, because they only have tatters" (Letter of the Francis de Sales "Tem- 
perance and Labour" association to the Government Delegate, 1922). All together he sheltered 83 boys, for whom he had to renovate 8 rented rooms, take care of electricity, plumbing, and heating, which cost 240,000 marks. In October, 1922 the "Temperance and Labour" Association received a subsidy from the Labour and Social Services Department to buy glass windows for the St. Francis de Sales boarding school (Documents of the Government Delegate in Wilno, 1923) and in March, 1923 56,000 marks to cover the costs of providing for 3 children from the Daniłow poviat living at the Home of the Heart of Jesus boarding school at $14 \mathrm{~W}$. Pohulanka street, and 37,300 marks for two children at the "Temperance and Labour" Association boarding school.

The boarding schools and shelters discussed above would typically house school age children.

The lack of funds sufficient to provide for the constantly increasing number of children and the often poor housing conditions were the problems encountered repeatedly.

The superior of the boarding school for girls at the Benedictine convent in Wilno described her problems in a letter to the Social Services Department. She states that: "because of the poor conditions of the Benedictine convent it is not possible for us to provide for the 15 orphans at the boarding school and to feed the further 17 girls at this boarding school from our meagre income" (To the Social Services Department from the head of the boarding school at the Benedictine convent, 1921). At the end of the letter the sister asks for a subsidy and a sazhen of firewood. From yet another letter one can learn that the Benedictines would also support 186 children from a nearby state school. The help consisted in preparing a warm breakfast. This letter is concluded with the following sentence: "please grant us a monthly subsidy for the poor children" (To the Social Services Department from the Superior of the convent A. Michaliczówna to the head of the Social Services Department, 1921).

Help was also required for the youngest children. They received constant care, or they would attend centres where they would be taken care of for a few hours a day. The latter were not only considered a form of help for working parents. The organisers also attempted to provide care and education for children of the unemployed by providing meals and the opportunity to spend time playing games for children. Occasionally clothes were distributed, as well. This work was done by nurseries, shelters, and orphanages. Although the names of the care and education institutions varied, their forms of their activity and the ways in which they supported children and parents were generally the same.

The institutions for the youngest children also had to face financial and housing difficulties. In an extensive letter, a doctor at the "Home of Baby Jesus" shelter discusses the abovementioned problems. She states that "according to the charter, the rooms of the shelter are intended for up to 100 children, from the first day of their lives to 4 years of age: currently we are housing 89 children of this age, and 108 older children, whom the Social Services Department has so far failed to take care of, despite our numerous requests for them to do so" (Documents of the Government Delegate in 
Wilno). The doctor emphasises that the lack of space at the shelter makes it unfeasible to provide the infants with sufficient care. She also mentions a number of other severe difficulties, such as the lack of a separate room for the ill, an observation room for newly admitted children, a day room for children aged 2 to 4 , which is why a part of this group has to spend their time in the bedrooms, and a part in the cold corridors. It is the opinion of the doctor that because the shelter is so crowded it is impossible to hire fully qualified personnel in necessary numbers. It draws the attention of the Health Department to the lack firewood, bed sheets, clothes, and, last but not least, diapers. The formulated postulates included the following: setting up a dairy kitchen for the infants and a regular payment of the subsidy, which also ought to be raised, in the opinion of the author.

In the reply to the above letter one can read: "because of the lack of a proper place for a new shelter and the lack of space in the existing shelters, the older children, over 4 years of age, cannot be taken away from the "House of Baby Jesus" (Documents of the Government Delegate in Wilno, 1923). To conclude the reply Labour and Social Services Department stated that the amount of the subsidy that the shelter was receiving for the board of the older children was sufficient, taking into account their number.

The work of the organisations and associations was aimed at helping children and state school students. Financial problems would appear for a number of years. Many organisations and associations could not cover the costs of the boarding of the poor, whose number did not decrease.

In the 1927 report on the work of the K. Zubowicz shelter in Wilno, which housed 111 children (boys and girls) it is written that: "Taking into account the financial issues, it was a difficult year. The necessity to provide the children with necessary clothing was hard on the clothes reserves of the Shelter, which were extremely scarce to begin with" (Financial report of the K. Zubowicz shelter in Wilno, 1927). In order to alleviate the shortages a charitable collection and a few charity shows were organised. The funds collected allowed the shelter to buy clothing. It is emphasised in the report that the building required constant renovation. It was most probably in order to cut the costs of maintenance that in April, 1927 the shelter rented 6 first floor rooms to a new institution: the Saint Thérèse of the Child Jesus Home. It was a secure care and education centre for pre-school age children (Report of the Saint Thérèse of the Child Jesus Home in Wilno from 1927 and the first quarter of 1928).

Evaluation of the work of the various centres leads to the conclusion that their aim was to provide children with food and clothing. The centres were established in order to help the poorest, for whom this help was the most important criterion in having a child admitted at a centre.

In Podbrodzie a group of women distributed food among pre-school age children. On 5 January, 1937, a nursery was established in order to organise this form of help. It was expected that the Voivodship Office in Wilno would subsidize the centre. No planned 
educational work was carried out, since the organisers claimed that "there is no one with sufficient qualifications to be found among the local population" (To the Voivodship Office in Wilno, Labour, Care and Health Department, 1936).

In the annual report of the "Day Nursery" ("Ochronka Dzienna") at 6 Dar street in Wilno, ran by the association of the Ladies of the Charity of Saint Vincent De Paul, it was emphasised that the aim of the centre is "to bring help to the poorest of the parents living in the Zarzecze and Puławy outskirts by taking care of their children" (Report of the Board of the "Day Nursery", 1937). The care mostly consisted in distributing food and clothing, as well as providing moral education of the children. Thanks to the subsidy of the Voivodship Office, it was possible for the nursery to organise summer day camps for 50 schoolchildren, most of whom had formerly attended the "Day Nursery".

Major organisations such as the Women Citizens Work Association (Związek Pracy Obywatelskiej Kobiet - ZPOK) and the Polish Mothers of Schoolchildren (Polska Macierz Szkolna - PMS) also expected to be financed by the Voivodship Office. In 1929, the Board of the Voivodship Association of the ZPOK applied for a subsidy to be spent on food for children. The board ran two centres in Wilno and two in Święciany and Mołodeczno. In the written application to the Labour and Social Services Department in Wilno one can read: "hunger drives more and more children to our nurseries, and our meagre finances prevent us from admitting and feeding their increasing numbers" (Documents of the Labour and Social Services Department. Open childcare centres, 1928-1929).

The documents present some actions of the social service organisations that may appear unjustified. In relation to ZPOK and the question of children from the poorest families I shall discuss the example of the work of the voivodship board of the association in 1937. In March, 1937, during a meeting of the members of the ZPOK department in Brasław a delegate of the voivodship structures of the ZPOK decided that the local nursery school be closed down. The rationale was that the financial situation of the parents who, according to the delegate, did not need the centre. During the discussion it was proven that such an opinion is ungrounded, since most of the children staying in the nursery school came from families of day labourers. When they were at work their children were left unattended. What is more, the question of the importance of the nursery to the intellectual and moral development of children was raised. The actions of the voivodship board called for an intervention of the Brasław poviat staroste in the Voivodship Office in Wilno (Brasław poviat staroste to the Voivodship Office in Wilno. Labour, Care and Health Department, Youth and childcare department, 1936-1938), which was aimed at preventing the liquidation of the nursery school.

Financial issues were a recurring subject in the correspondence between the ZPOK and the Voivodship Office. In the letters written in relation to the nursery in Nowe Troki the demand that the Voidvodship office pay for the nursery for 40 children and a dining room in which meals were to be given out to 180 children was raised. An application for a subsidy for a day room for 50 women and 20 men was submitted, as well. "The asso- 
ciation does not have the funds necessary for maintenance, because most of the money goes to feeding the children" (Board of the ZPOK Department in Nowe Troki to the Social Services Department at the Voivodship Office in Wilno, 1936). The Voivodship Office lowered the monthly subsidy for the nursery in Dzisno from 100 to 90 PLN. The board of the department informed the office that the number of children in the nursery increased from 40 to 79 . "Henceforth, we have to provide space and food for more children. In order to find place for all the children seeking admittance, it would appear to be necessary to establish another nursery" (Board of the ZPOK Department to the Wilno voivod, 1936). In the 1936/1937 annual report the Association Board informs that the centres in the Wileńsko-Trocki poviat "were established in the region inhabited by the poorest population. Running nurseries in these town and villages is a necessity, taking into consideration that, for example, the population of Nowa Wilejka is mostly unemployed, the population of Olkienniki is of mixed ethnicity, due to the closeness of the Polish-Lithuanian border, and the inhabitants of Troki are extremely impoverished, and they all cannot secure the basic conditions for their children's development" (Board of the ZPOK Association to the Voivodship Office in Wilno, Labour, Care and Health Department, 1939).

\section{Other forms of work with children, youth, and adults}

The activity of the organisations and associations intended for school-age and working youth would typically consist in establishing and running day rooms and clubs, as well as providing vocational training and opportunities to do sport.

For example, in 1921 it was recorded that a "Płomyk" ("The Flame") club for girls from secondary schools was organised. The idea of the weekly meetings (on Sundays from 2 to $5 \mathrm{PM}$ ) was to foster spiritual development and to teach the attendees self-study skills. An average of 50 girls took part in the Sunday meetings. The "Ognisko" ("The Bonfire") club was opened for adults. It was supervised by Anna Mohlówna. Social meetings and games were organised. Those interested could also use a library and a reading room. The Worker's House, in turn, was intended for working youth aged 16 to 23. The club members could participate in additional training courses, field trips, and sport. Sport was the main focus of the Polish Railwaymen Association (Polskie Towarzystwo Kolejarzy) and the Central Office of Christian Labour Unions (Centrala Chrześcijańskich Związków Zawodowych). Other organisations included the Youth Circle, associating the fans of the White Eagle theatre, and the Friends of Schoolchildren Society (Towarzystwo Przyjaciół Uczącej się Młodzieży), established in 1914, which started the "Ogniwo" ("The Chain Link") club for male and female youth. The club contained a library and a reading room, it was located at 8 Bernardyńska street in Wilno (Letter of the Friends of Schoolchildren Society Board to the Education Department, 1922). 
The organising of day rooms and clubs in state schools and other locations available to social service organisations produced good results. The most important of these was the care provided for children and youth after school classes. Financial problems were the only obstacles in the development of these efforts.

In February 1929, the Women's Social Service Association (Związek Pracy Społecznej Kobiet) applied to the Voivodship Office in Wilno for a 44,200 PLN subsidy to be used to organise twelve day rooms in state schools in the particular poviats of the Wilno voivodship and in the city of Wilno (Wilno Voividship Office, Labour and Social Services Department to the Ministry of Labour and Social Services. Social Services Department). When reading the reply of the Voivodship Office one may come to the conclusion that the administration was fully in support of the initiative, because "the poor children do not have the conditions to study at home, nor do they have the proper guidance or help" (Wilno Voividship Office, Labour and Social Services Department to the Ministry of Labour and Social Services, Social Services Department). In the further part of the letter it is stated that insufficient help is provided to the poor, which is why all initiatives of this type need to be supported. When justifying the subsidy application submitted to the Ministry the Voivodship Office argues that "because of the lack of socially conscious individuals in the poviat towns who could take decisive action and run dayrooms, it is not only desirable, but also indispensible that the government help to finance the day rooms" (Wilno Voividship Office, Labour and Social Services Department to the Ministry of Labour and Social Services. Social Services Department).

Working with the adult population was yet another matter. It is unfeasible to discuss all the forms of such work in the present paper, which is why I concentrate on homes of the people, open universities and folk high schools.

The Polish Mothers of Schoolchildren (PMS) association was among the social service organisations involved in work with adults.

For example, in the 1920/1921 annual report of the K. Promyk circle of the PMS in Wilno, established in 1920 by pr. N. Dyakowski, one can read: "The circle deals with promotion of national and social awareness among the poor inhabitants of the Wilcza Łapa outskirts" (K. Promyk Polish Mothers of Schoolchildren Circle in Wilno, Report on the work of the circle from 01.09.20 to 31.06.21). The circle ran a home of the people with a library. Throughout the accounting period 5 lectures and a knitting course for girls was organised in the home of the people. In 1921 further homes of the people were established in various districts of Wilno, along with libraries, and lectures and series of lectures were given. The PMS would carry out similar work in other towns and villages in the Wilno voivodship (Report of the Polish Mothers of Schoolchildren Board, 1921). The PMS organised additional education throughout the entire Interwar Period.

Numerous organisations and associations participated in setting up open universities and folk high schools. The Farmer's University in Prudiszcz in the Wilno poviat (full name: Wiejski Uniwersytet Społeczny - Farmer's Social University) was organised by 
the Voivodship Board of the Settlers' Association (Związek Osadników). The second university was started in November, 1937 in Żerno (Wołkowysk poviat), and another one in Dołhinów in the Wilejka poviat. The schools organised a few month long courses for older youth from the country, typically in the autumn and the winter. What was characteristic of the folk high schools was the so-called boarding system, which meant that students would stay at the school throughout the duration of the courses. That is why the number of attendees was limited. In 1937-1938 54 to 73 students participated in the courses organised at three folk high schools in the Wilno voivodship.

Being fully aware of the importance of providing additional education for adults the organisers started the so-called Sunday Universities, where series of lectures were given in the towns and villages where the potential attendees lived. Such a way of organisation made it possible to present a diversity of problems adjusted to the level of students' education (Table of the open and Sunday universities, 1937-1938). Houses of the people and day rooms organised by teachers in the local communities also need to be mentioned in the discussion of additional education. They were the places where people could meet the lecturers, and where meetings aimed at arriving at decisions crucial for the local communities were held.

\section{References}

Board of the ZPOK Department to the Wilno voivod, Wilno 24.10.1936, op. cit., op 12, No. 3036. Board of the ZPOK Department in Nowe Troki to the Social Services Department at the Voivodship Office in Wilno, op. cit., No. 3036.

Board of the ZPOK Association to the Voivodship Office in Wilno. Labour, Care and Health Department from 2.09.1939, op. cit., No. 3036.

Brasław poviat staroste to the Voivodship Office in Wilno. Labour, Care and Health Department, Youth and childcare department 1936-1938, op. cit., No. 3036.

Documents of the Voivodship Office in Wilno. Labour, Care and Health Department, Labour and care department, Youth and childcare department], f 51, op 12, No. 3409.

Documents of the Labour and Social Services Department. Open childcare centres 1928-1929, op. cit., No. 619.

Hartleb-Wojciechowska, Z. (1937). Rola i zadania samorządu na terenie województw wschodnich. Rocznik Ziem Wschodnich, 52.

Letter of the Friends of Schoolchildren Society Board to the Education Department. Wilno 19.07.1922, f 172, op 1, No. 347, 150.

Office of the Government Delegate in Wilno. Labour and Social Services Department. Francis de Sales “Temperance and Labour” boarding school] 15.11, f 51, op 15, No. 2585.

Srokowski, S. (1930). Podział administracyjny państwa a zagadnienie ustrojowe polskiego wschodu. Przegląd Współczesny, Issue 98, 343. 
Table of the open and Sunday universities 1937/38, f 172, op 1, No. 6688.

To the Social Services Department from the head of the boarding school at the Benedictine convent] Wilno 31.01.1921. Internat przy klasztorze p.p. Benedyktynek [Boarding school at the Benedictine convent], op. cit., No. 2586.

To the Social Services Department from the Superior of the convent A. Michaliczówna to the head of the Social Services Department. Wilno 14.01.1921. Internat przy klasztorze p.p. Benedyktynek, Boarding school at the Benedictine convent.

Wilno Voividship Office, Labour and Social Services Department to the Ministry of Labour and Social Services. Social Services Department. Warsaw, f 51, op 12, No. 619.

Wilno Childcare Association to the Social Services Department with the Government Delegate in Wilno. Documents of the Government Delegate in Wilno. Labour and Social Services Department, "Emergency Service" shelter for Christian children in Wilno, f 51, op 15, No. 2611.

\title{
Vaiku, jaunimo ir suaugusiuju globa ir švietimas Vilniaus vaivadijoje (1920-1939 m.)
}

\author{
Stefania Walasek \\ Vroclavo universitetas, Istorijos ir pedagogikos katedra, Pedagogikos institutas, \\ W. Dawida g. 1, 50-527 Vroclavas, Lenkija, s.walasek@wnhip.uni.wroc.pl
}

\section{Santrauka}

Antrosios Lenkijos Respublikos laikotarpiu Vilniaus vaivadija buvo priskiriama prie vargingiausių šalies rajonų. Dẻl to buvo svarbu imtis daugelio veiksmų kovojant su skurdu, nedarbu ir benamyste. Kadangi vaikų ir jaunimo situacija buvo ypač sunki, teko spręsti ekonomines, sveikatos ir švietimo problemas gerinant jų padètį. Kaip paaiškejjo, nei centrinè, nei vietos valdžia, veikdamos atskirai, tų problemų išspręsti negalëjo. Palyginti su kitais Lenkijos rajonais, šis rajonas buvo atsilikęs visu šimtmečiu, ir siekiant ịveikti tą didžiulị atotrūkị reikejo ne tik finansinių išteklių, bet ir didesnio visuomenès sąmoningumo.

Be centrinès ir vietos administracijos pastangų, svarbus vaidmuo teko atskirų asmenų ir organizacijų iniciatyvai, nes pastarieji veikè per ịvairias Vilniaus vaivadijos socialines grupes.

Būtina pažymèti, kad iš esmès ịvairios veiklos formos buvo sutelktos į materialinès paramos teikimą, aprūpinant gyventojus pastoge, maistu ir rūbais. Buvo rūpinamasi ir švietimo reikalais, tačiau pirmaisiais Antrosios Lenkijos Respublikos metais tai nebuvo pirmaeiliai reikalai. Gausiuose centruose dirbantis personalas nebuvo tinkamai profe- 
siškai pasirengęs. Analizuojant išlikusius tų centrų dokumentus matoma, kad tų pačių žmonių, dirbusių ir su vaikais, ir su jaunimu, pavardès nuolat kartojasi. Trečiojo dešimtmečio viduryje švietimo ir ugdymo klausimai iškilo ị pirmąją vietą, bet materialinès paramos teikimas ir toliau liko svarbiu organizacijų ir draugijų uždaviniu.

Nepaisant šiame straipsnyje nagrinėjamų sunkumų, kūrèsi ir veikè platus spektras ugdymo ir globos institucijų: globos ir švietimo centrai, mokyklos, kursų programos, darželiai, našlaičių namai, dienos centrai, liaudies kultūros namai, atvirieji universitetai, suaugusiųjų švietimo mokyklos. Vietos aktyvistams pavyko sudominti gyventojus dienos stovyklomis, vasaros stovyklomis, sveikatos centrais ir vadinamosiomis kaimo vaikų stovyklomis. Tačiau visą šią ịvairialypę veiklą nutraukẻ Antrasis pasaulinis karas.

Esminiai žodžiai: globa, auklejjimas, ugdymas, Vilniaus vaivadija.

Iteikta / Received 2013-12-15

Priimta / Accepted 2014-11-29 